\title{
Morphological Variability and Taxonomic Relationship of Sorghum bicolor (L.) Moench Accessions Based on Qualitative Characters
}

\author{
Ika Nugraheni Ari Martiwi ${ }^{1}$, Laurentius Hartanto Nugroho ${ }^{2}$, \\ Budi Setiadi Daryono ${ }^{2}$ and Ratna Susandarini ${ }^{2 *}$
}

${ }^{1}$ Faculty of Science and Technology, State Islamic University Sunan Kalijaga, Indonesia.

${ }^{2}$ Faculty of Biology, Universitas Gadjah Mada, Indonesia.

\begin{abstract}
Authors' contributions
This work was carried out in collaboration among all authors. Author INAM conceived research idea, designed research methodology, carried out literature search and conducted data collection. Author

LHN managed literature review, managed data interpretation, read and approved the manuscript.

Author BSD conceived idea, managed literature review, read and approved the manuscript. Author $R S$ designed research methodology, performed statistical analysis, managed data interpretation and wrote the manuscript. All authors read and approved the final manuscript.

Article Information

DOI: $10.9734 / A R R B / 2020 / v 35 i 630234$

Editor(s):

(1) Paola Angelini, University of Perugia, Italy.

(2) Dr. Rishee K. Kalaria, Navsari Agricultural University, India.

Reviewers:

(1) Zeinab Kanani, Taif University, Saudi Arabia.

(2) Muzafer Ahmad Sheikh, University of Jammu, India.

Complete Peer review History: http://www.sdiarticle4.com/review-history/58713
\end{abstract}

Original Research Article

Received 23 April 2020

Accepted 29 June 2020

Published 01 July 2020

\section{ABSTRACT}

Sorghum bicolor (L.) Moench is a member of Poaceae family with three agronomic types corresponds to their specific uses namely grain sorghum, sweet sorghum, and forage sorghum. Although sorghum in Indonesia is considered as under-utilized crop, but it has the potential as an alternative resource for staple food in diversification program to support food security. The potential of sorghum as alternative staple food is due to its high nutritional value, and the ability to grow well in marginal lands with maintaining good productivity. The objectives of this study were to assess the extent of morphological variability and to resolve taxonomic relationship of sorghum accessions from Java Island based on morphological characters. Twenty nine sorghum samples were collected from three provinces in Java, namely Central Java, Special Province of Yogyakarta, and East Java. 
Morphological data observed refers to Descriptors for Sorghum, generating 19 qualitative characters used in cluster analysis and principal component analysis. Cluster analysis resulted in the grouping of 29 accessions into three groups corresponding to the racial classification of sorghum. Results of principal component analysis showed that the main distinguishing characters between groups were inflorescence compactness and shape, glume coverage, presence or absence of awn, presence or absence of grain sub-coat, grain shape, and grain color. Analysis of correlation showed that there were very strong relationship between glume coverage and the presence of awn, and between the presence of grain sub-coat and grain color. Results of this study revealed that sorghum accessions cultivated on Java Island consisted of four races namely Bicolor, Guinea, Caudatum, and Kafir.

Keywords: Sorghum; morphology; phonetics; characterization; classification.

\section{INTRODUCTION}

S. bicolor is one of food crop that is well adapted to grow in marginal lands, withstands dry and hot conditions while still maintaining high productivity [1]. Based on its utilization, S. bicolor is divided into three categories, namely gain sorghum for human consumption which is rich in carbohydrate, forage sorghum for animal feed, and sweet sorghum which is harvested for its stems to be processed into sugar, syrup and other derivatives [2]. Grain sorghum is one of staple food in arid and semi-arid regions of Asia, Africa, and Central America [3]. Sorghum as staple food has many advantageous properties including high fiber content, low gluten, low glycemic index, and contains many phytochemical compounds including phenolic acids, anthocyanin, phytosterols, polycosanols and tannins [4].

From taxonomical point of view, diversity in S. bicolor is reflected in racial classifications which are mainly based on inflorescence characteristics. S. bicolor is known to have 5 main races, namely Bicolor, Guinea, Kafir, Caudatum, and Durra [5,6]. In addition, because of the ability of cross-pollination, there are 10 intermediate races recognized which are combinations of the five main races within S. bicolor.

Studies on morphological characterization of plants with high morphological variability have important role as a basis for identifying phenotypic and genotypic diversity of a species. The knowledge on phenotypic and genotypic diversity is very important especially for cultivated plants such as sorghum that have undergone long selection process during domestication [7]. Phenotypic characterization through assessment of morphological variation plays an important role in identifying diagnostic characters determining genotypic differences [8], which are useful for conservation of genetic resources [9].

Most of sorghum diversity studies were carried out in African regions, such as the morphological variation of wild and weedy sorghum in Kenya [10], agro-morphological diversity of sorghum in South Africa [11], phenotypic variability of sorghum from Northwestern Benin [12], agromorphological variability of sorghum cultivars in Chad [9], and morphological characterization of sorghum in Ethiopia [13].

Sorghum in Indonesia is considered as minor and least utilized crop receives inadequate attention and thus faces the risk of decreasing its diversity in nature. Similar concern on sorghum which was underestimated for its potential has been mentioned [14]. In responding to this concern, there is a need for exploring the diversity and potential value of sorghum landraces for the conservation of alternative food resource. While most of Indonesian consumes rice as staple food, the sporadic existence of S. bicolor in many areas of Java Island offers the opportunity to explore the diversity of this species. Based on preliminary field observations, sorghum in Java Island exhibit morphological variability, with three commons variants were recognized namely sorghum accessions with white, red, and brown grains. Publications on sorghum diversity in Indonesia were generally come from the eastern part of the country, particularly from East Nusa Tenggara [15,16]. A research on sorghum in Java was still very limited with the aim to observe the suitability of dry land in Gunungkidul [17]. Meanwhile, recent publication on the diversity and morphological characterization of sorghum from Java Island was still limited to nine accessions from East Java [18].

In this study, assessment of morphological variability was done on sorghum accessions collected from three provinces in Java. Analysis 
on qualitative morphological characters was used as the basis for recognizing the existence of sorghum races cultivated in Java Island. Qualitative characters referred in this study are attributes of a given accessions in the form of categorical data, as mentioned in the morphological descriptions of accessions, excluding sizes and numbers. Qualitative characters are represented in the form of nominal, ordinal, or binary data. Furthermore, phenetic relationships of sorghum accessions were determined using multivariate methods, and discussion on taxonomic relationship in 29 sorghum accessions under study was presented accordingly.

\section{MATERIALS AND METHODS}

Sample collection was done in seven districts covering three provinces in Java Island. Determination of sample locations was based on information obtained from relevant government agencies and from the public. A total of 29 accessions (Table 1) were collected from
February to October 2019. Examination of qualitative characters for the assessment of morphological variability referred to Descriptors for Sorghum [19], including the determination of numerical scores for the analysis of taxonomic relationships. The use of qualitative characters in this study referred to previous studies on the analysis of morphological variations of sorghum landraces $[11,15,16]$. The numerical taxonomic methods used to reveal the grouping of sorghum accessions were cluster analysis and principal component analysis. Cluster analysis was performed based on Euclidean distance and Unweighted Pair Group Method using Arithmetic Average (UPGMA) clustering procedure. The principal component analysis (PCA) was carried out to identify patterns of morphological character variation. Characters that showed major contribution in the grouping accessions based on the results PCA were subjected to correlation analysis using Pearson formula. Cluster analysis and principal component analysis were performed using PAST software version 4.02 [20].

Table 1. List of sorghum accessions

\begin{tabular}{|c|c|c|c|}
\hline No. & Code & Collection site (District and Province) & Vernacular name \\
\hline 1. & WNS 01 & Gunungkidul, Yogyakarta Special Province & tebon lutung \\
\hline 2. & WNS 02 & Gunungkidul, Yogyakarta Special Province & tebon putih \\
\hline 3. & WNS 03 & Gunungkidul, Yogyakarta Special Province & tebon plenthung ireng \\
\hline 4. & WNS 04 & Gunungkidul, Yogyakarta Special Province & tebon abang \\
\hline 5. & WNS 05 & Gunungkidul, Yogyakarta Special Province & tebon coklat abang \\
\hline 6. & WNS 06 & Gunungkidul, Yogyakarta Special Province & mrico \\
\hline 7. & WNS 07 & Gunungkidul, Yogyakarta Special Province & tebon plenthung abang \\
\hline 8. & WNS 08 & Gunungkidul, Yogyakarta Special Province & tebon taun abang \\
\hline 9. & WNS 09 & Gunungkidul, Yogyakarta Special Province & tebon taun ungu \\
\hline 10. & WNS 10 & Gunungkidul, Yogyakarta Special Province & lutung ketan \\
\hline 11. & WNS 11 & Gunungkidul, Yogyakarta Special Province & ndolo \\
\hline 12. & BTL 01 & Bantul, Yogyakarta Special Province & cantel coklat \\
\hline 13. & BTL 02 & Bantul, Yogyakarta Special Province & cantel abang \\
\hline 14. & BTL 03 & Bantul, Yogyakarta Special Province & cantel abang \\
\hline 15. & BTL 04 & Bantul, Yogyakarta Special Province & cantel putih \\
\hline 16. & BTL 05 & Bantul, Yogyakarta Special Province & cantel abang \\
\hline 17. & SLM 01 & Sleman, Yogyakarta Special Province & cantel ireng \\
\hline 18. & WNG 01 & Wonogiri, Central Java & tebon ketan \\
\hline 19. & WNG 02 & Wonogiri, Central Java & tebon coklat \\
\hline 20. & WNG 03 & Wonogiri, Central Java & tebon abang \\
\hline 21. & WNG 04 & Wonogiri, Central Java & tebon ketan coklat \\
\hline 22. & DMK 01 & Demak, Central Java & sorgum lokal \\
\hline 23. & LMG 01 & Lamongan, East Java & $K D 4$ \\
\hline 24. & LMG 02 & Lamongan, East Java & numbu \\
\hline 25. & LMG 03 & Lamongan, East Java & orean ketan \\
\hline 26. & BJN 01 & Bojonegoro, East Java & jagung jepe ireng \\
\hline 27. & BJN 02 & Bojonegoro, East Java & cantel abang coklat \\
\hline 28. & BJN 03 & Bojonegoro, East Java & sorgum coklat ketan \\
\hline 29. & BJN 04 & Bojonegoro, East Java & sorgum coklat merah \\
\hline
\end{tabular}




\section{RESULTS AND DISCUSSION}

Observations of morphological characters on 29 sorghum accessions resulted in the documentation of 19 qualitative characters which showed variability between samples (Table 2). These nineteen characters were examined from stems, leaves, inflorescence, glumes, and grains. Among these 19 characters, the inflorescence compactness and shape has the highest variability, with 7 types of inflorescences were recognized in accessions under study (Fig. 1). Previous studies on sorghum morphological variability conducted in other countries also reported high variation in types of inflorescence, and it was found that inflorescence compactness and shape was predominant character in the grouping of sorghum landraces from Ethiopia [21]. Studies showing high variability of inflorescence compactness and shape have also been reported on sorghum accessions from Pakistan [22] and sorghum landraces from Benin [23]. Inflorescence compactness is one of morphological characters indicating the domestication history of sorghum through selection of desirable traits, and become a key character in determining whether particular cultivar is classified as primitive or advance in evolutionary context [5].

Glume morphological characters showed remarkable variations, such as the presence or absence of awn (Fig. 2), glume color, and glume coverage (Fig. 3). The presence or absence of awn is one of the important characters in the racial classification of sorghum [6], and this character is beneficial for certain sorghum cultivars since the presence of awn prevents the grains from being eaten by birds [24]. The character of glume coverage, or the degree of glume enclosing over the grains, showed high variability which can be classified into four categories namely $25 \%, 50 \%, 75 \%$, and $100 \%$ coverage. The variation in glume coverage was believed to be related to threshability [24] and also related to morphological adaptations that facilitate the rapid drying process of grains so that minimizing the risk of grain mould [13].

Table 2. Qualitative morphological characters of Sorghum bicolor

\begin{tabular}{|c|c|c|}
\hline Character & Code & Character states \\
\hline Plant color * & $\mathrm{PCL}$ & $\begin{array}{l}1=\text { pigmented }(\text { grey-brown group 199A) } \\
2=\tan (\text { greyed }- \text { yellow group 161B) }\end{array}$ \\
\hline Stalk juiciness & STJ & $\begin{array}{l}0=\text { not juicy (dry) } \\
1=\text { juicy }\end{array}$ \\
\hline Juice flavor & SJF & $\begin{array}{l}1=\text { sweet } \\
2=\text { insipid }\end{array}$ \\
\hline Waxy bloom & SWB & $\begin{array}{l}3=\text { slightly present } \\
5=\text { medium } \\
7=\text { bloomy }\end{array}$ \\
\hline Leaf color & LCL & $\begin{array}{l}1 \text { = light green } \\
2=\text { dark green }\end{array}$ \\
\hline Leaf sheath pigmentation & LSP & $\begin{array}{l}0=\text { absent } \\
1=\text { present }\end{array}$ \\
\hline $\begin{array}{l}\text { Inflorescence compactness } \\
\text { and shape }\end{array}$ & ICS & $\begin{array}{l}1=\text { very lax panicle } \\
2=\text { very loose } \text { drooping primary branches } \\
3=\text { loose, drooping primary branches } \\
4=\text { semi-loose }, \text { erect primary branches } \\
5=\text { semi-loose, drooping primary branches } \\
6=\text { semi-compact elliptic } \\
7=\text { compact elliptic }\end{array}$ \\
\hline Inflorescence exertion & IFE & $\begin{array}{l}1=\text { slightly exerted }(<2 \mathrm{~cm}) \\
2=\text { exerted }(2-10 \mathrm{~cm}) \\
3=\text { well-exerted }(>10 \mathrm{~cm})\end{array}$ \\
\hline Stigma color & ISC & $\begin{array}{l}1=\text { white } \\
2=\text { yellow }\end{array}$ \\
\hline Glume color * & GCL & $\begin{array}{l}1=\text { mahogany (greyed-orange group 164B, 164A, } \\
165 \mathrm{~B}, 165 \mathrm{~A}) \\
2=\text { red (orange-red group 33C, 33B, 33A, 34A) } \\
3=\text { purple (greyed-purple group 183D, 183C, 183B, }\end{array}$ \\
\hline
\end{tabular}




\begin{tabular}{|c|c|c|}
\hline Character & Code & Character states \\
\hline & & $\begin{array}{l}183 \mathrm{~A}) \\
4=\text { black (black group 202A; brown group 200A) }\end{array}$ \\
\hline Glume covering & GCV & $\begin{array}{l}1=25 \% \\
3=50 \% \\
5=75 \% \\
7=100 \% \text { (grain fully covered by glumes) }\end{array}$ \\
\hline Awn & GAW & $\begin{array}{l}0=\text { absent (awnless) } \\
1=\text { present }(\text { awned })\end{array}$ \\
\hline Shattering & GST & $\begin{array}{l}3=\text { low } \\
5=\text { intermediate } \\
7=\text { high }\end{array}$ \\
\hline Grain shape & GSH & $\begin{array}{l}1=\text { round } \\
2=\text { biconvex } \\
3=\text { oval } \\
4=\text { elliptical }\end{array}$ \\
\hline Grain color * & GCL & $\begin{array}{l}1=\text { white (white group 155d, 155c, 155b, 155a) } \\
2=\text { yellow (yellow group 6d, 6c, 6b, 6a) } \\
3=\text { red (orange-red group 33c, 33b, 33a, 165b, } \\
165 a \text { ) } \\
\begin{array}{l}4=\text { brown (greyed-orange group 164b, 164a, 165b, } \\
165 a \text { ) }\end{array}\end{array}$ \\
\hline Grain sub-coat & GSC & $\begin{array}{l}0=\text { absent } \\
1=\text { present }\end{array}$ \\
\hline Grain plumpness & GPL & $\begin{array}{l}3=\text { dimple } \\
7=\text { plump }\end{array}$ \\
\hline Endosperm texture & ETX & $\begin{array}{l}3=\text { corneous } \\
5=\text { intermediate } \\
7=\text { starchy }\end{array}$ \\
\hline Endosperm color * & $\begin{array}{l}\mathrm{ECL} \\
\text { on } R o \text { s }\end{array}$ & $\begin{array}{l}1=\text { white (white group 155B) } \\
2 \text { = yellow (greyed-yellow group 162A) } \\
\text { rticultural Society }(R H S) \text { color codes }\end{array}$ \\
\hline
\end{tabular}

Fig. 1. Variation on inflorescence compactness and shape: A. very lax panicle; B. very loose, drooping primary branches; C. loose, drooping primary branches; D. semi-loose, erect primary branches; E. semi-loose, drooping primary branches; F. semi-compact elliptic;

\section{G. compact elliptic}




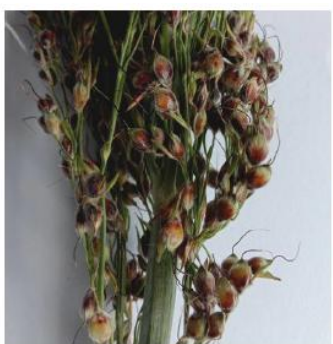

$\mathbf{A}$

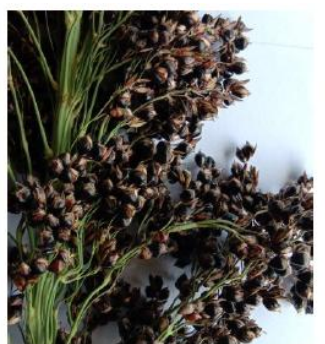

B

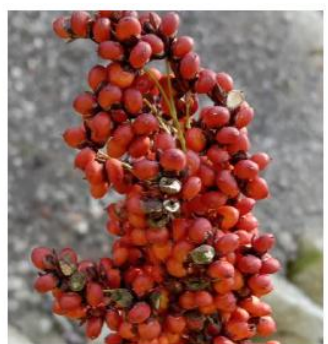

C

Fig. 2. Variation on the presence and absence of awn: A. awned glumes with extension,B. awned glumes without extension, $C$. awnless glumes

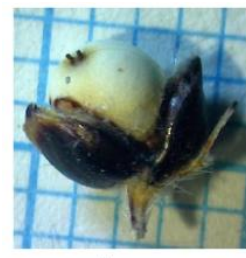

A

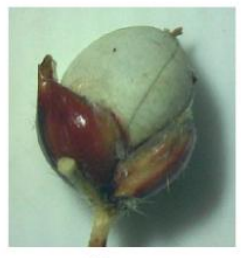

D

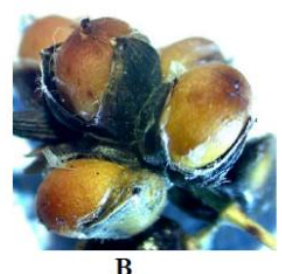

B

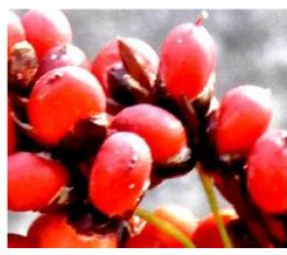

E

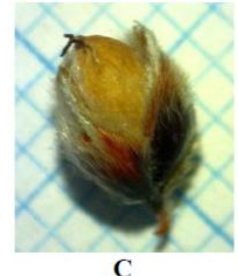

C

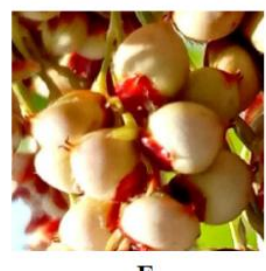

Fig. 3. Variation on glume color and glume coverage: A. black glume, $100 \%$ coverage; B. black glume, $75 \%$ coverage; $C$. mahogany glume, $75 \%$ coverage; $D$. mahogany glume, $50 \%$ coverage; E. purple glume, $25 \%$ coverage; $F$. red glume, $25 \%$ coverage

Grain morphological characters also showed notable variations, including grain color, grain shape, and the presence or absence of grain sub-coat. Grain color could be distinguished into white, yellow, red, and brown (Fig. 4). Grain color is related to anthocyanin content [25] or total phenolic compound which obviously correlates to antioxidant activity [26]. In this case sorghum accessions with red and brown grains have high content of total phenolic compounds and shows high antioxidant activity. Variation in grain color is believed as the result of deliberate artificial selection related to grain utilization by the local community, such as in Ethiopia -in whichwhite grain sorghum was used as food, while red or brown grain sorghum was used for brewing traditional alcoholic beverages [13].

Overall, the high morphological variability among the sorghum accessions in this study was found in the morphology of inflorescence, glumes, and grains. The results of this study were similar to those reported for sorghum landraces from Benin [23], in that panicle compactness, glume color, and grain color were the most varied qualitative characters. The same result was noted on sorghum landraces in Ethiopia which showed high variability in inflorescence characters, glume coverage, and grain color [13].

Result of cluster analysis as displayed in the dendrogram (Fig. 5) showed that 29 sorghum accessions were divided into two main clusters. The cophenetic correlation coefficient of the dendrogram generated from cluster analysis was 0.859 . The cophenetic correlation coefficient is used to verify the quality of grouping generated from cluster analysis [27]. The value of 0.859 indicated very good clustering results, in which the clusters formed based on Euclidean distance and UPGMA procedure were convincingly reflected the degree of similarity or differences between samples. 


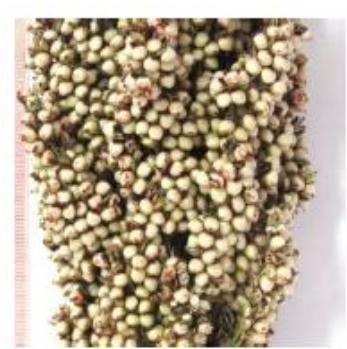

white

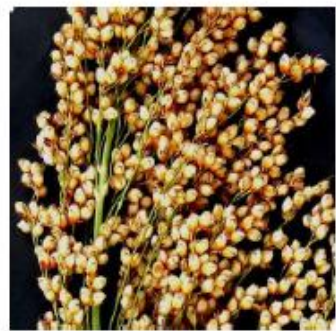

yellow

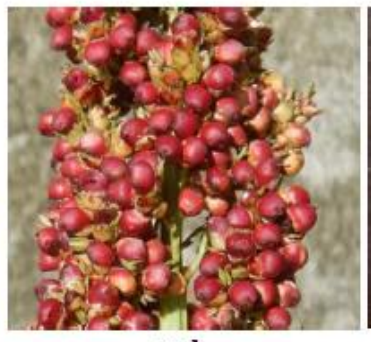

red

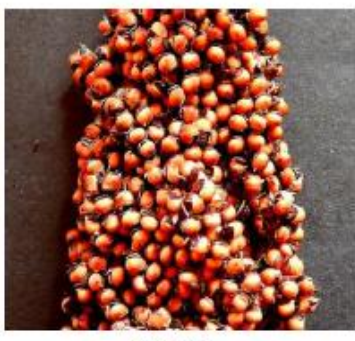

brown

Fig. 4. Variations on sorghum grain color

Ex.lidean Distance

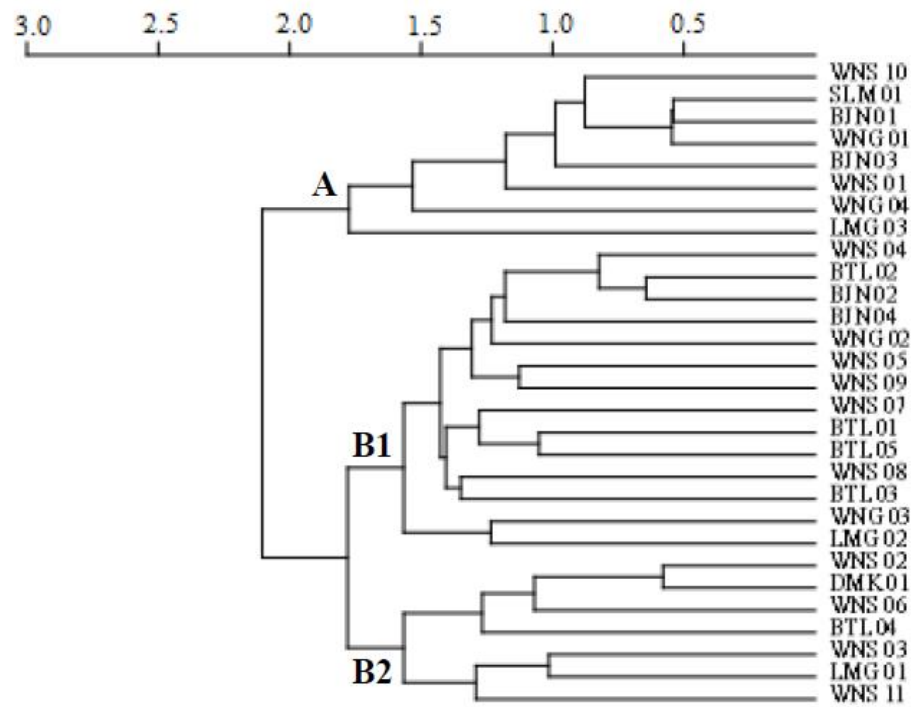

Fig. 5. Dendrogram showing the grouping of 29 sorghum accessions based on 19 qualitative morphological characters

The first cluster marked here as group A was consisted of 8 accessions, while the second cluster marked as group B was comprised of 21 accessions. The major distinguishing characters of the two clusters include the type of inflorescence, glume coverage, and the presence or absence of awn. The members of cluster A were characterized by the inflorescence type of very loose or loose panicles, glume coverage of $75 \%$ or $100 \%$, and awned glumes. Cluster B were consisted of sorghum accessions with the main characteristics of semi-loose, semi-compact or compact inflorescence, $25 \%$ or $50 \%$ glume coverage on the grains, and glumes without awn. Cluster B was clearly divided further into two sub-clusters, which were referred here as subclusters B1 and B2. The main differences between the two sub-clusters were grain color, the presence or absence of grain sub-coat, and grain shape. Sub-cluster B1 consisted of sorghum accessions that have grain sub-coats, red or brown grains, and oval or elliptical grain shapes. The members of sub-cluster B2 were sorghum accessions that do not have grain subcoat, white grain color, and round grainshape.

The grouping pattern in the dendrogram showed a clear separation of accessions based on the main characters commonly used to recognize differences in sorghum phenotype. The wellstructured clustering between groups indicated genetic divergence. This finding had similar pattern with the study on phenotypic diversity of forage sorghum and grain sorghum genotypes in Uganda which showed clear distinction between the two genotype groups [28]. The grouping pattern of sorghum accession into their respective clusters and sub-clusters also did not 
show separation based on their geographical origin. This result indicated that the phenotypic diversity reflected through morphological differences observed in this study was due to underlying genetic factors, and was not influenced by the environmental conditions where they grow. Similar results were found in a study on sorghum from Ethiopia [3,29]. In such a study in South Africa showed that the grouping of accessions was not based on the place of origin, instead it was due to several factors including the sharing of grains among farmers from different locations and the active role of farmers in deliberately conserving certain sorghum accessions in their fields [11].

Confirmation on the distinguishing characters determining formation of clusters and subclusters in the dendrogram was provided by the results of principal component analysis presented in Table 3. Results of principal component analysis showed that the first two principal components (PC1 and PC2) accounted for $52.588 \%$ of total variance. Three characters showed important contribution on the separation of 29 sorghum accessions into two clusters in the dendrogram, as indicated by the absolute loadings of $>0.3$ on the first principal component. These three characters were glume coverage, inflorescence compactness and shape, and the presence or absence of awn. The second principal component was associated with other three characters of notable contribution in the formation of two sub-clusters, the B1 and B2 in the dendrogram. These three characters were grain color, the presence or absence of grain sub-coat, and grain shape.

The grouping patterns of accessions resulted from cluster analysis was in agreement with the result of principal component analysis as displayed in the scatterplot of sorghum accessions (Fig. 6). There is a mathematical relationship between the two multivariate analysis methods [30]. Results of this studies confirmed the role of PCA as a method complementary to cluster analysis, as has been mentioned in previous study on morphological variation using multivariate analysis [31,32]. In this case PCA has important role in identifying morphological variation patterns [23] and in determining the relative contribution of characters to the variations found in samples under study [3]. Due to its complementary role, PCA was commonly used in conjunction with cluster analysis in taxonomic studies at family, genus, and species level such as those reported on Amaranthaceae [33], Abelmoschus [34], and Mangifera indica [35]. Accordingly, combination of these two multivariate analysis methods, the cluster analysis and PCA, has also been applied widely in sorghum diversity studies $[12,27,28,36$, 37].

Table 3. Character loadings, eigenvalue, and percent variance from PCA

\begin{tabular}{lll}
\hline Character code* & PC 1 & PC 2 \\
\hline PCL & -0.088 & -0.141 \\
STJ & -0.243 & -0.075 \\
SJF & 0.112 & 0.137 \\
SWB & 0.046 & 0.165 \\
LCL & 0.006 & 0.068 \\
LSP & 0.143 & 0.197 \\
ICS & -0.449 & 0.178 \\
IFE & 0.004 & 0.132 \\
SCL & -0.013 & 0.003 \\
GCL & 0.215 & 0.156 \\
GCV & 0.590 & -0.434 \\
GAW & 0.352 & -0.115 \\
GST & 0.217 & -0.011 \\
GSH & 0.127 & 0.378 \\
GCL & 0.279 & 0.491 \\
GSC & 0.165 & 0.454 \\
GPL & 0.026 & -0.120 \\
ETX & -0.097 & -0.071 \\
ECL & 0.021 & -0.035 \\
Variance (\%) & ${ }^{*}$ character codes refer to those mentioned in Table 2 \\
Cummulative variance (\%) & 16,463 \\
\hline
\end{tabular}




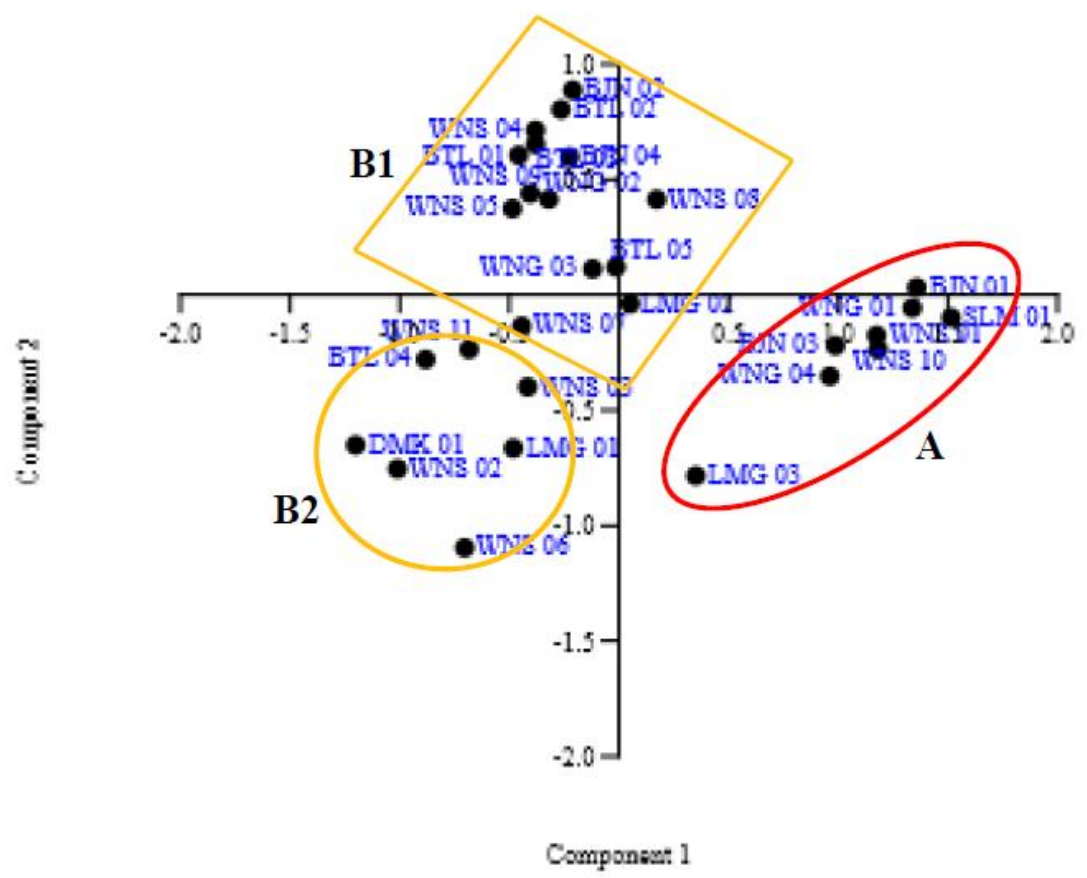

Fig. 6. Scatterplot of 29 sorghum accessions resulted from principal component analysis

Table 4. Correlation coefficient of six morphological characters

\begin{tabular}{|c|c|c|c|c|c|c|}
\hline Character & ICS & GCV & GAW & GSH & GCL & GSC \\
\hline ICS & 1 & & & & & \\
\hline GCV & -0.726 & 1 & & & & \\
\hline GAW & -0.726 & 0.787 & 1 & & & \\
\hline GSH & -0.149 & -0.037 & 0.194 & 1 & & \\
\hline GCL & -0.337 & 0.294 & 0.385 & 0.271 & 1 & \\
\hline GSC & -0.167 & 0.167 & 0.128 & 0.416 & 0.743 & 1 \\
\hline
\end{tabular}

To determine the association between the six characters that showed considerable contribution in the grouping of accessions, a correlation analysis was performed. Based on the Pearson's correlation coefficient shown in Table 4, there are very strong correlations found in two pairs of characters. The first was between GCV and GAW a as indicated by Pearson's correlation coefficient of 0.787 , and the second one was between GCL and GSC with correlation coefficient of 0.743 . The very strong relationship between GCV and GAW was evidently shown in sorghum accessions which have full or nearly full $(75 \%-100 \%)$ glume coverage over the grains, they were all have awn in their glumes. A very strong positive correlation between GCL and GSC was shown by the fact that sorghum accessions with grain color red or brown were notably have grain sub-coat.
Meanwhile there are also interesting facts in which two pairs of qualitative characters showed very strong negative correlations as indicated by the correlation coefficient of -0.726 . The first pair was between ICS and GCV which means that when the inflorescence increases in their compactness, the glume coverage over the grains gradually decrease. This relationship was clearly observed in which most of sorghum accessions with compact inflorescence had glume coverage of $25 \%$ on their grains. The second pair of characters showing strong negative relationship was between ICS and GAW, which means that when the inflorescence becomes more compact there is very strong tendency towards the absence of glumes. In this case it was quite obvious that sorghum accessions with semi-compact or compact inflorescence they were all have awnless glumes. 
Correlation analysis has been used in many studies exploring sorghum morphological variability to estimate of the degree of linear association between characters [3,38]. Information on the correlation among characters is important for the selection of genotype with desirable traits especially when dealing with quantitative traits related to yield [11].

The grouping of 29 sorghum accessions resulted from cluster analysis also showed conformity with the racial classification of sorghum. The separation of sorghum accessions into botanical races was clearly structured in the dendrogram, showed the existence and solid grouping of four races, namely Bicolor, Guinea, Kafir, and Caudatum. The morphological characters of eight accessions in the first group (cluster A) clearly indicated that they consisted of Bicolor and Guinea races.

Accessions which belong to Bicolor race were WNS10, SLM01, and BJN01. These three accessions had inflorescence type of very lax panicle (SLM01) or very loose drooping primary branches (WNS10 and BJN01), with darkcolored, biconvex or ovate grains which were enclosed by thick, awned and hairy glumes. These characters were typical morphology of Bicolor race [6]. The other five accessions (WNG01, BJM03, WNS01, WNG04, LMG03) were clearly showed the typical characteristics of Guinea race. The Guinea race was characterized by long, loose and pendulous panicles, and darkcolored, ovate grains which are almost enclosed (75\% coverage) by open, hairy, awned glumes $[6,39]$.

The members of sub-cluster B1 which consisted of 14 accessions had a combination of characters typical for Kafir race. They could be easily recognized by erect, semi-compact panicles bearing elliptical, red or brown colored grains covered by short, awnless glumes which cover $25 \%-50 \%$ over the grains [6]. Meanwhile, the members of sub-cluster B2 have compactelliptic panicles, and distinctive round-shaped, chalky white grains covered by short, awnless glumes covering $25 \%-50 \%$ of the grains. These seven accessions were notably showed morphological characteristics of Caudatum race [6].

The identification of four sorghum races revealed in this study clearly showed the predominance of Kafir race. This finding was different from sorghum diversity study from East Nusa
Tenggara that were dominated by Bicolor race, with the occurrence of Guinea and Kafir races at a lesser number [16]. Different results were found from sorghum racial diversity studies in other countries, such as in sorghum accessions collected from Northwestern Benin which showed predominance of Guinea race without any representative of Kafir race [12]. The dominant occurrence of Guinea race was also reported on sorghum accessions collected from Senegal [38], and in sorghum cultivars collected in Chad which only consisted of Durra race [9].

\section{CONCLUSION}

This study contributes considerably in updating sorghum diversity profile in Java Island by identifying the existence of four sorghum botanical races and their taxonomic relationships based on morphological characters. The high morphological variability and its corresponding racial diversity of sorghum revealed in this study indicated a considerable degree of genotypic diversity. Taxonomic relationships among sorghum accessions are very important for the improvement programs as well as conservation of sorghum in Indonesia. The existence of four botanical races obviously showed high intraspecific diversity of sorghum in Java Island today. This fact also showed that although Java Island has the highest population density in Indonesia, it still holds important food resources potential to be developed for diverse utilization. The results of this study also provide scientific basis for the preservation of local food resources to support food security.

\section{ACKNOWLEDGEMENTS}

This research was financially supported by Research Grant from Universitas Gadjah Mada under the scheme of Thesis Recognition Program (RTA 2020) granted for the corresponding author (Dr. RatnaSusandarini).

\section{COMPETING INTERESTS}

Authors have declared that no competing interests exist.

\section{REFERENCES}

1. Turner MF, Heuberger AL, Kirkwood JS, Collins CC, Wolfrum EJ, Broeckling CD, Prenni JE, John CE. Non-targeted metabolomics in diverse sorghum breeding 
lines indicates primary and secondary metabolite profiles are associated with plant biomass accumulation and photosynthesis. Frontiers in Plant Science. 2016;7:953.

DOI: $10.3389 /$ fpls.2016.00953

2. Alhajturki D, Al Jamali $M$, Kanbar A. Genetic variation of sorghum (Sorghum bicolor L. Moench) varieties assessed by ISSR Markers. Advances in Environmental Biology. 2011;5:3504-3510.

3. Derese SA, Shimelis $H$, Mwadzingeni $L$, Laing $\quad M$. Agro-morphological characterisation and selection of sorghum landraces. ActaAgriculturaeScandinavica, Section B - Soil \& Plant Science. 2018; 68(7):585-595.

DOI: $10.1080 / 09064710.2018 .1448884$

4. Alfieri M, Balconi C, Cabassi G, Habyarimana E, Redaelli R. Antioxidant activity in a set of Sorghum landraces and breeding lines. Maydica. 2017;62: M23.

5. Dahlberg JA. Classification and characterization of sorghum. In: Smith CW, Frederiksen RA (Eds.). Sorghum: Origin, History, Technology, and Production. John Wiley \& Sons, Inc. New York; 2000.

6. Dahlberg JA. Classifying the genetic diversity of sorghum: A revised classification of sorghum. In: Rooney W. (Ed.) Achieving Sustainable Cultivation of Sorghum Volume 1: Genetics, Breeding and Production Techniques. Burleigh Dodds Science Publishing, Cambridge, UK; 2018.

DOI:http://dx.doi.org/10.19103/AS.2017.00 15.02

7. Ayana A, Bekele E. Geographical patterns of morphological variation in sorghum (Sorghum bicolor (L.) Moench) germplasm from Ethiopia and Eritrea: Quantitative characters. Euphytica. 2000;115:91-104.

8. Bhusal N, Pahuja SK, Vats AK, Srivastava A, Kumar RS. Morphological characterization of forage sorghum genotypes for its various DUS traits. Journal of Applied and Natural Science. 2017;9(2):912-919.

9. Naoura G, Sawadogo N, Atchozou EA, Emendack Y, Hassan MA, Reoungal D, Amos DN, Djirabaye N, Tabo R, Laza $\mathrm{H}$. Assessment of agro-morphological variability of dry-season sorghum cultivars in Chad as novel sources of drought tolerance. Scientific Reports. 2019;9: 19581.
DOI:https://doi.org/10.1038/s41598-01956192-6

10. Okeno JA, Mutegi E, de Villiers S, Wolt JD, Misra MK. Morphological variation in the wild-weedy complex of Sorghum bicolor in situ in Western Kenya: Preliminary evidence of crop-to-wild gene flow? International Journal of Plant Sciences. 2012;173(5):507-515.

DOI: http://dx.doi.org/10.1086/665266

11. Mofokeng AM, Shimelis HA, Laing MD. Agromorphological diversity of South African sorghum genotypes assessed through quantitative and qualitative phenotypic traits. South African Journal of Plant and Soil. 2017;34(5):361-370.

DOI: 10.1080/02571862.2017.1319504

12. Missihoun AA, Adoukonou-Sagbadja $H$, Ezin V, Sedah P, Dagba RA, Ahanhanzo C, Agbangla C. Phenotypic variability and racial classification of landraces of sorghum (Sorghum bicolor (L.) Moench) collected in the Northwestern Benin. International Journal of Agronomy and Agricultural Research. 2015;7(4):23-35.

13. Gebrie G, Genet T. Morphological characterization and evaluation of sorghum [Sorghum bicolor (L.) Moench] landraces in Benishangul Gumuz, North-western Ethiopia. Greener Journal of Agricultural Sciences. 2019;9(1):37-56.

DOI:http://doi.org/10.15580/GJAS.2019.1.1 23118187

14. Muui CW, Muasya RM, Kirubi DT. Identification and evaluation of sorghum (Sorghum bicolor (L.) Moench) germplasm from Eastern Kenya. African Journal of Agricultural Research. 20138(37):45734579.

DOI: $10.5897 / A J A R 11.1519$

15. Mukkun L, Lalel HJD, Richana N, Pabendon MB, Kleden SR. The diversity of local sorghum (Sorghum bicolor L. Moench) in Nusa Tenggara Timur province. IOP Conf. Series: Earth and Environmental Science. 2018;144:012065. DOI :10.1088/1755-1315/144/1/012065

16. Tnunay IMY, Chikmawati T, Miftahudin. Morphological Diversity of Local Sorghum Cultivar (Sorghum bicolor) of East Nusa Tenggara, Indonesia. Biosaintifika: Journal of Biology \& Biology Education. 2019; 11(1):47-54

DOI:http://dx.doi.org/10.15294/biosaintifika .v11i1.15199

17. Muttaqin AS, Gunardi, Kusuma FA. Suitability analysis of Sorghum based on 
rainfall and land condition in Gunungkidul Indonesia. Proceeding of International Conference on Climate Change. 2016;242247.

18. Sulistyawati, Roeswitawati D, Ibrahim JT, Maftuchah. Genetic diversity of local sorghum (Sorghum bicolor) genotypes of East Java, Indonesia for agromorphological and physiological traits. Biodiversitas. 2019;20:2503-2510.

DOI: $10.13057 /$ biodiv/d200910

19. IBPGR and ICRISAT. Descriptors for Sorghum [Sorghum bicolor (L.) Moench]. International Board for Plant Genetic Resources, Italy; International Crops Research Institute for the Semi-Arid Tropics, Patancheru, India; 1993.

20. Hammer $\varnothing$, Harper DAT, Ryan PD. PAST: Paleontological Statistics Software Package for Education and Data Analysis. Palaeontologia Electronica. 2001;4(1)art. 4:9.

Available:http://palaeoelectronica.org/2001_1/past/issue1_01.htm

21. Abdi A, Bekele E, Asfaw Z, Teshome A. Patterns of morphological variation of sorghum (Sorghum bicolor (L.) Moench) landraces in qualitative characters in North Shewa and South Welo, Ethiopia. Hereditas. 2002;137:161-172.

22. Durrishahwar, Noor $M$, Hidayat-urRahman, Ihteramullah, Shah IA, Ali F, Shah SMA, Mehmod N. Characterization of sorghum germplasm for various morphological and fodder yield parameters. African Journal of Biotechnology. 2012;11(56):11952-11959. DOI: $10.5897 / A J B 11.4000$

23. Dossou-Aminon I, Loko LY, Adjatin A, Ewédjè EBK, Dansi A, Rakshit $S$, Cissé N, Patil JV. Genetic divergence in Northern Benin sorghum (Sorghum bicolor $\mathrm{L}$. Moench) landraces as revealed by agromorphological traits and selection of candidate genotypes. The Scientific World Journal. 2015;Article ID 916476:10.

DOI:http://dx.doi.org/10.1155/2015/916476

24. Verma R, Ranwah BR, Bharti B, Kumar R, Kunwar R, Diwaker A, Meena M. Characterization of sorghum germplasm for various qualitative traits. Journal of Applied and Natural Science. 2017;9(2): 1002-1007.

25. Su X, Rhodes D, Xu J, Chen X, Davis H, Wang D, Herald TJ, Wang W. Phenotypic diversity of anthocyanins in sorghum accessions with various pericarp pigments.
Journal of Nutrition \& Food Sciences. 2017;7:610.

DOI:10.4172/2155-9600.1000610

26. Choi SC, Kim JM, Lee YG, Kim C. Antioxidant activity and contents of total phenolic compounds and anthocyanins according to grain colour in several varieties of Sorghum bicolor (L.) Moench. Cereal Research Communications. 2019; 47(2):228-238.

DOI: $10.1556 / 0806.47 .2019 .14$

27. Carvalho PR, Munita CS, Lapolli AL. Validity studies among hierarchical methods of cluster analysis using cophenetic correlation coefficient. International Nuclear Atlantic Conference INAC 2017, Brazil, October 22-27, Associação Brasileira de Energia Nuclear - ABEN; 2017.

28. Chikuta S, Odong T, Kabi F, Rubaihayo P. Phenotypic diversity of selected dual purpose forage and grain sorghum genotypes. American Journal of Experimental Agriculture. 2015;9(6):1-9.

DOI: 10.9734/AJEA/2015/20577

29. Desmae H, Jordan DR, Godwin ID. Geographic patterns of phenotypic diversity in sorghum (Sorghum bicolor (L.) Moench) landraces from North Eastern Ethiopia. African Journal of Agricultural Research. 2016;11(33):3111-3122.

DOI: 10.5897/AJAR2016.11121

30. Ugwuanyim GU. The usefulness of clustering and principalcomponent analysis in the classification of plants to species level. African Journal of Natural Sciences. 2000;3:29-36.

31. Matheri F, Mwangi M, Runo S, Ngugi M, Kirubi DT, Teya F, Mawia AM, Kioko FW, Kamau DN. Phenotypic characterization of selected Kenyan purple and yellow passion fruit genotypes based onmorphoagronomic descriptors. Advances in Crop Science and Technology. 2016;4(4):226. DOI: 10.4172/2329-8863.1000226

32. Mulima E, Sibiya J, Musvosvi C, Nhamucho E. Identification of important morphological traits in Mozambican sorghum [Sorghum bicolor (L.) Moench] germplasm using multivariate analysis. African Journal of Agricultural Research. 2018;13(34):1796-1810. DOI: 10.5897/AJAR2018.13316

33. Roy B, Mukhopadhyay B, Paria ND. Phenetic analysis of seedling morphology of some members of Amaranthaceae. Research Journal of Life Sciences, 
Bioinformatics, Phamaceutical and Chemical Sciences. 2019;5(3):301-321.

DOI: $10.26479 / 2019.0503 .25$

34. Patil P, Sutar S, Malik SK, John J, Yadav $\mathrm{S}$, Bhat KV. Numerical taxonomy of AbelmoschusMedik. (Malvaceae) in India. Bangladesh Journal of Plant Taxonomy. 2015;22(2):87-98.

35. Igbari AD, Nodza GI, Adeusi AD, Ogundipe OT. Morphological characterization of mango (Mangifera indica L.) cultivars from South-West Nigeria. Ife Journal of Science. 2019;21(1):155-163.

DOI:https://dx.doi.org/10.4314/ijs.v21i1.13

36. Sinha S, Kumaravadivel N. Understanding genetic diversity of sorghum using quantitative traits. Scientifica. 2016;Article ID3075023:8.

DOI:http://dx.doi.org/10.1155/2016/307502 3

37. Kavithamani D, Yuvaraja A, Selvi B. Principal component analysis and grouping of sorghum (Sorghum bicolor L. Moench) gene pool for genetic diversity. Electronic Journal of Plant Breeding. 2019;10(4): 1426-1434.

DOI: 10.5958/0975-928X.2019.00182.0

38. Kanbar A, Shakeri E, Alhajturki D, Horn T, Emam Y, Tabatabaei SA, Nick $P$. Morphological and molecular characterization of sweet, grain and forage sorghum (Sorghum bicolor L.) genotypes grown under temperate climatic conditions, Plant Biosystems - An International Journal Dealing with all Aspects of Plant Biology; 2019.

DOI: $10.1080 / 11263504.2019 .1569568$

39. Gueye T, Sine B, Cisse N, Diatta C, Ndiaye S. Characterization of phenotypic diversity of sorghum collection for developing breeding material. International Journal of Sciences. 2016; 5(2):38-48.

DOI: 10.18483/ijSci.931.

(c) 2020 Martiwi et al.; This is an Open Access article distributed under the terms of the Creative Commons Attribution License (http://creativecommons.org/licenses/by/4.0), which permits unrestricted use, distribution, and reproduction in any medium, provided the original work is properly cited.

Peer-review history:

The peer review history for this paper can be accessed here: http://www.sdiarticle4.com/review-history/58713 